\title{
Object and Means of University-Firm Technology Transfer
}

\author{
Daniela Althoff Philippi ${ }^{1}$, Emerson Antonio Maccari², Priscila Rezende da Costa ${ }^{2 *}$
}

\begin{abstract}
Greater demand for food and the scarcity of natural resources reinforce the importance of research at universities and the transfer of their technologies to firms, particularly in the case of crops. In this context, the general aim of this study is to analyze the alignment of the object and means of university-firm technology transfer in Brazilian and American agriculture schools. The research is qualitative in nature, with multiple case studies of two American universities and a Brazilian university, selected using criteria such as excellence, accessibility and technological similarities. Among the results and contributions to the field, the innovations that were generated and the identification of the differences and similarities in formal and informal processes of university-firm technology transfer may be highlighted.
\end{abstract}

Keywords: Object and means of technology transfer; universities; firms; innovation; agriculture.

Submitted: March $14^{\text {th }}, 2018 /$ Approved: August $14^{\text {th }}, 2018$

\section{Introduction}

The USA, due to its concept of universities and innovation incentive policies, stand out on the world scene in terms of university-firm technology transfer (U-FTT), with the Bayh-Dole Act of 1980, promoting innovation processes resulting from university-firm (U-E) interaction (Mowery \& Sampat, 2005; Siegel et al., 2003; Mowery et al., 2001; Jensen \& Thursby, 2001; Henderson et al., 1998). Furthermore, an embedded culture of innovation and interaction is consolidated as one of the main mechanisms for the development and diffusion of technologies. Meanwhile, in developing countries like Brazil, this process is hindered by outdated S\&T policies that are often ineffective and slowed down by a bloated bureaucracy, lack of investment in research and backward technology. All of these factors lead to an incipient culture of U-F interaction, with few patents and innovations resulting from research (Garnica \& Torkomian, 2009; Stal \& Fujino, 2005; Melo, 2002; Alves, 2015; WEF, 2015).

Considering the peculiar aspects of the USA and Brazil's national innovation systems, and in an attempt to learn from successful experiences, the general objective of this study is to analyze the alignment of the object and means of university-firm technology transfer at agriculture schools in Brazilian and American universities.

Despite the difficulties involved in U-FTT, and considering the shorter production cycles and lack of structure in companies for technological development with their own resources, there is growing interest in relationships with universities that result in benefits for both firm and university (Etzkowitz \& Leydesdorff, 2000). It is understood that the USA enjoy greater technological development and a closer relationship between academia and organizations compared with Brazil. These factors, combined with the importance of agribusiness in the Brazilian context (with a considerable share of GDP) and international context, with a rising population creating a greater demand for food in the face of scarce natural resources, emphasize the importance of this study, particularly with regard to crops.

\section{Literature Review}

U-FTT is the passing of knowledge generated by a university to a company, enabling it to innovate and increase its technological capacity to obtain a competitive advantage in the market (Zucker \& Darby, 2001; Closs \& Ferreira, 2012; Ankrah \& Omar, 2015; De Fuentes \& Dutrénit, 2016).

U-FTT can be classified as formal or informal. Formal technology transfer lies in the means of transferring a research result into a patent or license to use the technology, including property rights. In informal transfer, this outcome is not expected (Lee, 1996; Grimpe \& Fier, 2010; Lai, 2011; Miller et al., 2018; Baglieri et al., 2018). Link, Siegel and Bozeman (2007), Grimpe and Fier (2010) and, more recently, Bradley, Hayter and Link (2013), demonstrated the need for greater attention to informal technology transfer as the focus of studies. According to Grimpe and Fier (2010), examples of informal technology transfer could be contact between members of academia and firms at conferences, in joint publications, academic consultancies and other informal contacts like conversations and meetings. Bradley, Hayter and Link (2013) add further examples, such as technical assistance and joint (cooperative) research.

When it comes to theoretical models on U-FTT, the Contingent Effectiveness Model of Technology Transfer of Bozeman (2000) stands out, as it prioritizes the effectiveness of results. Furthermore, elements and criteria of effectiveness in TT are presented and, as the name suggests, it is 'contingent', enabling the inclusion of new variables (Bozeman, 2000). The model considers formal and informal TT (Bozeman, 2000), and authors such as Grimpe and Fier (2010), Link et al. (2007), Bradley et al. (2013) and Bigliardi, Marolla and Verbano (2015), point out the importance of studying informal TT informal. This is because, despite being widely used in practice, few studies have addressed the theme.

In the model by Bozeman (2000), the effectiveness criteria of technology transfer involve (1) out-the-door, (2) market impact, (3) economic development, (4) political reward, (5) opportunity costs and (6) scientific and technical human capital. The properties of these criteria and the resulting research propositions are presented below.

(1) Federal University of Mato Grosso do Sul, Aquidauana, Mato Grosso do Sul, Brasil

(2) Universidade Nove de Julho (UNINOVE), São Paulo, Brasil,

${ }^{*}$ Corresponding author: priscilarezende@yahoo.com.br 
Table 1. Theoretical construct of the study regarding effectiveness criteria of U-FTT processes.

\begin{tabular}{lll}
\hline Categories & Properties & Authors \\
\hline (1) Out-the- door & $\begin{array}{l}\text { Compliance with delivery deadlines; receipt of TT as agreed; distribution of } \\
\text { resources (payment) as agreed; checking for dissatisfaction with received te- } \\
\text { chnology. }\end{array}$ & $\begin{array}{l}\text { (Bozeman, 2000; Rosenberg \& Nelson, 1994; } \\
\text { 1996; Bozeman et al., 1995). }\end{array}$ \\
\hline (2) Market impact & Product realization; profitability; larger market share and increase in sales. & (Bozeman, 2000) \\
\hline (3) Economic development & $\begin{array}{l}\text { Creation of new jobs; new jobs downstream and upstream; new business } \\
\text { downstream and upstream. }\end{array}$ & (Bozeman, 2000; Harmon et al., 1997). \\
\hline (4) Political reward & Public recognition through TT: for the agent and recipient. & (Bozeman, 2000; Crow \& Bozeman, 1998; Di \\
& $\begin{array}{l}\text { Gregorio \& Shane, 2003; Zucker \& Darby, 2001; } \\
\text { O'Shea et al., 2005). }\end{array}$ \\
\hline (5) Opportunity cost & $\begin{array}{l}\text { Losses or gains of TT in relation to laboratories, equipment, training and mis- } \\
\text { sion }\end{array}$ & $\begin{array}{c}\text { (Bozeman, 2000; Crow \& Bozeman, 1998; } \\
\text { Woerter, 2004). }\end{array}$ \\
\hline $\begin{array}{l}\text { (6) Scientific and technical } \\
\text { human capital }\end{array}$ & $\begin{array}{l}\text { Greater participation in collaboration networks and workgroups and more } \\
\text { people available; } \\
\text { More people available; greater scientific production (articles) }\end{array}$ & $\begin{array}{l}\text { (Bozeman \& Rogers, 1998; Lynn } \text { et al., 1996; Bi- } \\
\text { dault \& Fischer, 1994; Malecki, 1981; Malecki } \\
\text { \& Tootle, 1996). }\end{array}$
\end{tabular}

\section{Method}

The study is qualitative in nature as it is a more in-depth study of relationships, processes and phenomena. Furthermore, it is predominantly based on the testimony of the participants (Minayo et al., 1994; Eisenhardt, 1989).

The approach is exploratory (Babbie, 1998; Cervo \& Bervian, 1983; Eisenhardt, 1989), as priority was given to understanding University-Firm Technology Transfer to discover new propositions for the
Bozeman's (2000) Contingent Effectiveness Model of Technology Transfer.

This study specifically addresses a multiple case study (Yin, 2001): Brazilian University (BU) and American University (AU). The analysis units were three Technology Transfer processes, specifically involving the agricultural school and firms, namely Processes ALPHA and BETA at the American University (AU) and Process GAMMA, connected with the Brazilian University (BU), with details provided in the following table.

Table 2. Summary of the characteristics of selected U-FTT processes. Source: Prepared by the authors.

\begin{tabular}{|c|c|c|c|}
\hline Details of the U-FTT & \multicolumn{3}{|c|}{ Selected U-FTT processes } \\
\hline Object of TT & Variety of sweet potato & $\begin{array}{l}\text { Discovery of } 1-\mathrm{MCP} \text { properties } \\
\text { (vegetables, especially fruit) }\end{array}$ & Variety of ginger \\
\hline Means of TT & Crop & Patent & $\begin{array}{c}\text { Registered with Ministry of } \\
\text { Agriculture }\end{array}$ \\
\hline Main benefits & Evenness and resistance & $\begin{array}{l}\text { Delays ripening (better } \\
\text { conservation) }\end{array}$ & Resistance \\
\hline
\end{tabular}

Concerning data collection, the chosen procedure was the interview (13 in all), with the instrument being the interview script. The subjects who participated in the interviews were: the people in charge of the technology transfer nuclei of universities $\mathrm{AU}$ and $\mathrm{BU}$, selected teaching staff involved in U-FTT processes and directors of the recipient organizations of the transferred technology.
Creswell (2014) claims that in a multiple case analysis, a typical format is to proceed first with a detailed description of each case, known as a 'within-case analysis'. This is followed by a thematic analysis across the cases, called a cross-case analysis, in addition to assertions or an interpretation of the meaning of the cases. In the joint analysis, the convergence or non-convergence of the cases was verified, albeit not 
limited to the previously established propositions and seeking evidence of the positions inherent to each case and highlighting the aspects of the American and Brazilian contexts and their relationship with the cases.

\section{Results and Discussions}

Regarding the nature of the technology transfers (Table 3), whether product or process, all were defined as products. However, Beta is an applicable product, integrating a process to delay ripening and is $\mathrm{cu}-$ rrently applied especially to fruit. Alpha and Gamma are new varieties of plants (vegetables) with superior characteristics, especially in terms of productivity. In the case of Alpha, the new product (a variety of sweet potato) provides higher income through conservation and a more standardized format of sweet potato. This latter characteristic is particularly advantageous for the processing industry, especially for restaurants. The benefits of Alpha extend to the entire production chain, since demand for this type of sweet potato is high, due to its superior characteristics. Concerning Gamma, a new variety of ginger still in the experimental stage, its primary benefit lies in its resistance to pests. This aids the economic activity of small farmers who wish to grow it or return to growing this crop, thus providing more business for Gamma.
The creation of new enterprises (spinoffs and startups) or new businesses from Alpha's TT occurred indirectly, but in the long term, with new second-generation products, enabling some farmers to expand and supply new markets. Alpha's TT favored the creation of products such as vodka, also called Alpha, and purified sweet potato mash, which led to the opening of a new company. In the case of Beta, the technology, initially adapted to the flower market, led to the creation of the Florabloc product, when the recipient, the object of this study, created a new subsidiary because of this technology. With the newly adapted technology, the BetaFresh product was created, for application to a range of fruits, creating differentiated products in its application and with adaptation to other fruits and regions, with incremental innovations in the USA and the rest of the world. As for Gamma's TT, it is not possible to make accurate predictions, but there is the possibility of supplying natural and processed ginger to the Brazilian market and even overseas. It is believed that small farmers, with incentives and support from private and public programs, can develop new businesses (Table 3)

The TT aspects of the empirical cases in question are summarized in the following table:

Table 3. Aspects related to the object of TT in the three cases.

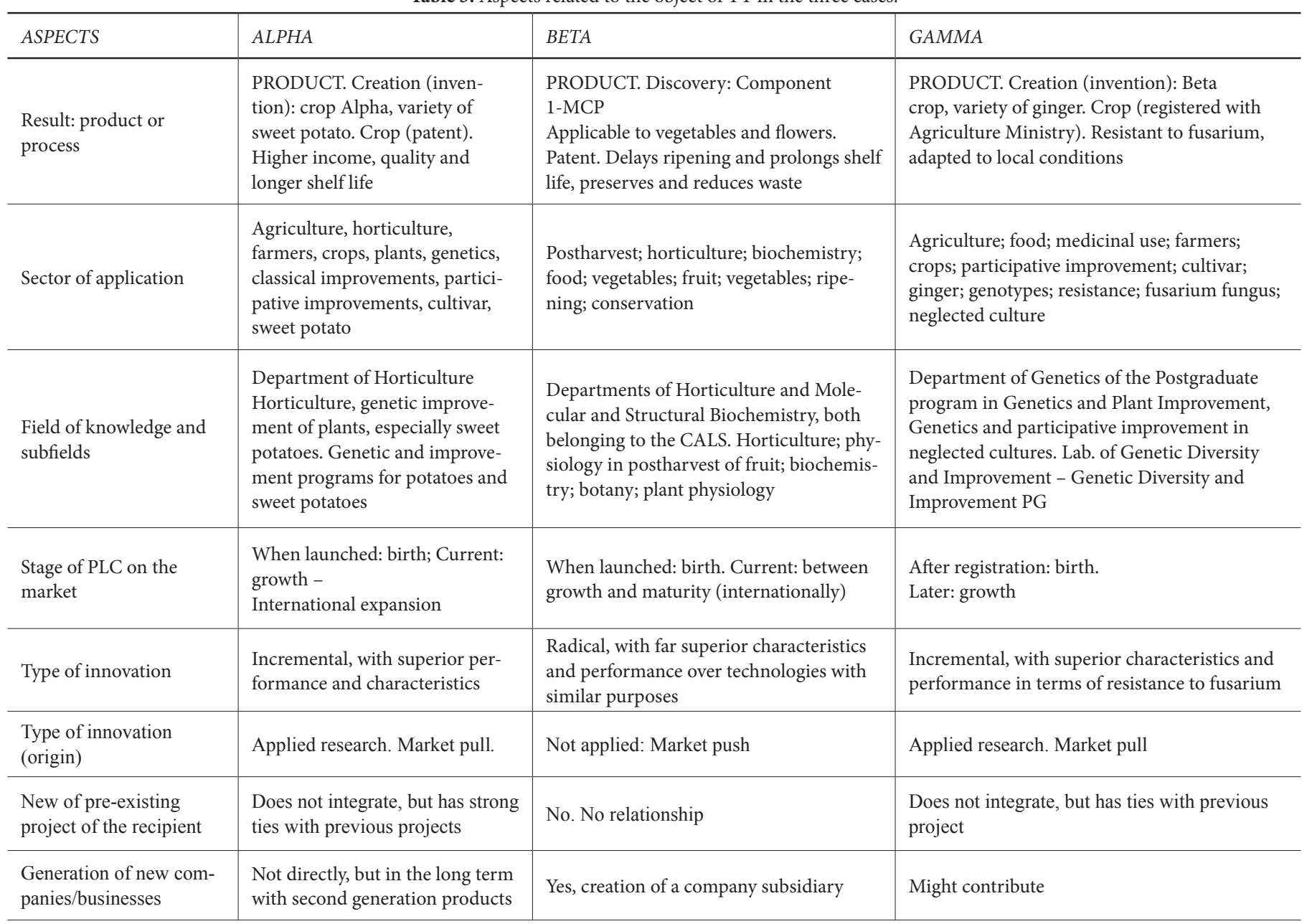


Concerning the three cases of technology transfer analyzed at AU (TT processes of Alpha and Beta) and BU (TT process of Gamma), in the following table, the means adopted for TT are summarized, along with the reasons for choosing the means, the elements involved (people and organizations), the time involved and the sources and amounts of resources (Table 4).

Regarding the means: Case Alpha is a patented crop, whereas Gamma is an unpatented crop that is only registered at the Ministry of Agriculture, as there is no commercial interest (in commercial gain through marketing) on the part of the TT agent, BU. Both Alpha and Gamma use participatory improvement as a means, as the primary user is actively participating. Therefore, efforts regarding technology are pre-directed. In the case of Beta, the discovery of the component (Beta technology) was a random one, when combining a research project with another purpose (Table 4).

Concerning the motives for choosing the means, for both Alpha and Gamma, as they are a new variety of plant, the means is the crop. In the case of Alpha, the "patenting of the variety" was considered a pioneer step by the agent and the recipient, who had worked without patents and licensing. These were motivated by legislation, but also by the need for further resources to continue research. AP2 mentioned that without the resources earned from licensing, with the withdrawal of public funding, the research programs would not be as advanced as they are (Table 4).

Concerning the source and amount of resources, in none of the cases was the sum invested in the development of the technologies up to the 'point of marketing' revealed. State investments were included in all cases either directly (case Alpha) or indirectly (Beta and Gamma). In the case of Alpha, the farmers, officially organized into a Commission, invested directly in the technology, which also occurred when Beta was marketed, but with the necessary adaptation to the market. In the case of Gamma, the technology cost less and the resource required was the soil for planting (location of the field experiment). The other resources were acquired from the physical structure of BU and the departmental resources and doctorate scholarship. The American researchers in the cases of Alpha and Beta mentioned their salaries as part of the investment, while the Brazilian researchers made no reference to this (Table 4).

Table 4. Aspects related to the means of TT in the three cases.

\begin{tabular}{|c|c|c|c|}
\hline $\begin{array}{l}\text { ASPECTS/ } \\
\text { AGENTS OF TT }\end{array}$ & ALPHA (AU - Commission) & $\begin{array}{l}\text { BETA } \\
\text { (AU-BetaFresh) }\end{array}$ & $\begin{array}{l}G A M M A \\
(B U-G A M A)\end{array}$ \\
\hline Means adopted & $\begin{array}{l}\text { Formal TT: crop. Non-exclusive license - } \\
\text { international } \\
\text { Participative Improvement Project for } \\
\text { Farmers (Sweet Potato Improvement } \\
\text { Program of AU) }\end{array}$ & $\begin{array}{l}\text { Formal TT: exclusive licensed patent - } \\
\text { international } \\
\text { Research project funded by the US Dept. } \\
\text { of Agriculture (other purpose) }\end{array}$ & $\begin{array}{l}\text { Informal TT: crop (Ministry of Agriculture). } \\
\text { No license. North coast of São Paulo. } \\
\text { Research Project (doctorate) Participative } \\
\text { improvement of ginger }\end{array}$ \\
\hline $\begin{array}{l}\text { Reasons for choosing } \\
\text { means }\end{array}$ & $\begin{array}{l}\text { Variety of plant. Non-exclusive license: } \\
\text { available to many farmers }\end{array}$ & $\begin{array}{l}\text { Technology applicable to plants. } \\
\text { Exclusive license. The size of the second } \\
\text { company may have further enabled } \\
\text { the exclusive use as it is an active } \\
\text { multinational }\end{array}$ & $\begin{array}{l}\text { Variety of plant. Crop only registered, } \\
\text { no commercial interest of researchers; } \\
\text { alternative income for small farmers } \\
\text { Lacks BU structure for quicker process }\end{array}$ \\
\hline $\begin{array}{l}\text { Elements involved } \\
\text { (people and } \\
\text { organizations) }\end{array}$ & $\begin{array}{l}\text { Permanent: Two researchers, one a } \\
\text { professor, the other not (improvers) of } \\
\text { AU (Department of Horticulture) } \\
\text { Commission of farmers. } \\
\text { Not permanent: other researchers of the } \\
\text { AU; laboratory technician; farmers; state } \\
\text { extension agents; ETT external office } \\
\text { (legal area); } \\
\text { Board of Directors of the CALS }\end{array}$ & $\begin{array}{l}\text { Permanent: two researchers/professors } \\
\text { at AU (Departments of Horticulture and } \\
\text { Molecular and Structural Biochemistry). } \\
\text { Not Permanent: Post-doctorate } \\
\text { candidate; ETT; Flowers; TT facilitators; } \\
\text { colleague from the department and } \\
\text { Flowers; Agrobeta }\end{array}$ & $\begin{array}{l}\text { Permanent: doctoral researcher and two } \\
\text { researchers/professors. Post-graduate } \\
\text { project in Genetics and Plant Improvement; } \\
\text { owner of Gamma; farmer at Gamma. Not } \\
\text { permanent: extension agent from research } \\
\text { institute, other farmers }\end{array}$ \\
\hline Time involved & $\begin{array}{l}\text { Launch: between } 2005 \text { and } 2006 \\
\text { Crop registered in } 2008 \text {. } \\
\text { Immediate use: farming commission }\end{array}$ & $\begin{array}{l}\text { Development and launch: early 1990s. } \\
\text { Patent granted: } 1996 . \text { Uses: } 1999 \text { - } \\
\text { decorative plants - Flowers; } 2002 \text { - } \\
\text { apples (EPA) - by AgroBeta }\end{array}$ & $\begin{array}{l}\text { Development: from } 2012 \text { to } 2016 \text { (GP3). } \\
\text { Launch and registration (2016). Use: } \\
\text { Gamma and farmers in the region }\end{array}$ \\
\hline $\begin{array}{l}\text { Source and amounts } \\
\text { of resources involved }\end{array}$ & $\begin{array}{l}\text { Sources of resources. Participative } \\
\text { Improvement of Farmers Project. } \\
\text { CBDCN Association of Development } \\
\text { for the harvest run by the State. State } \\
\text { (stations) } \\
\text { AU structure (physical and salaries). } \\
\text { Amount of resources: not informed }\end{array}$ & $\begin{array}{l}\text { Sources of resources: research project } \\
\text { (US Department of Agriculture for } \\
\text { another purpose); AU structure } \\
\text { (physical/salaries). Amount of resources: } \\
\text { not informed }\end{array}$ & $\begin{array}{l}\text { Source of resources: CNPq Scholarship } \\
\text { Department - Doctorates. BU structure } \\
\text { (physical). Amount of resources: not } \\
\text { informed }\end{array}$ \\
\hline
\end{tabular}




\section{Discussions related to aligning the object and the means of technology transfer}

The following table summarizes the theoretical assumption regarding the object of TT and the empirical cases:

Table 5. Theoretical assumptions related to the object of TT in the three cases.

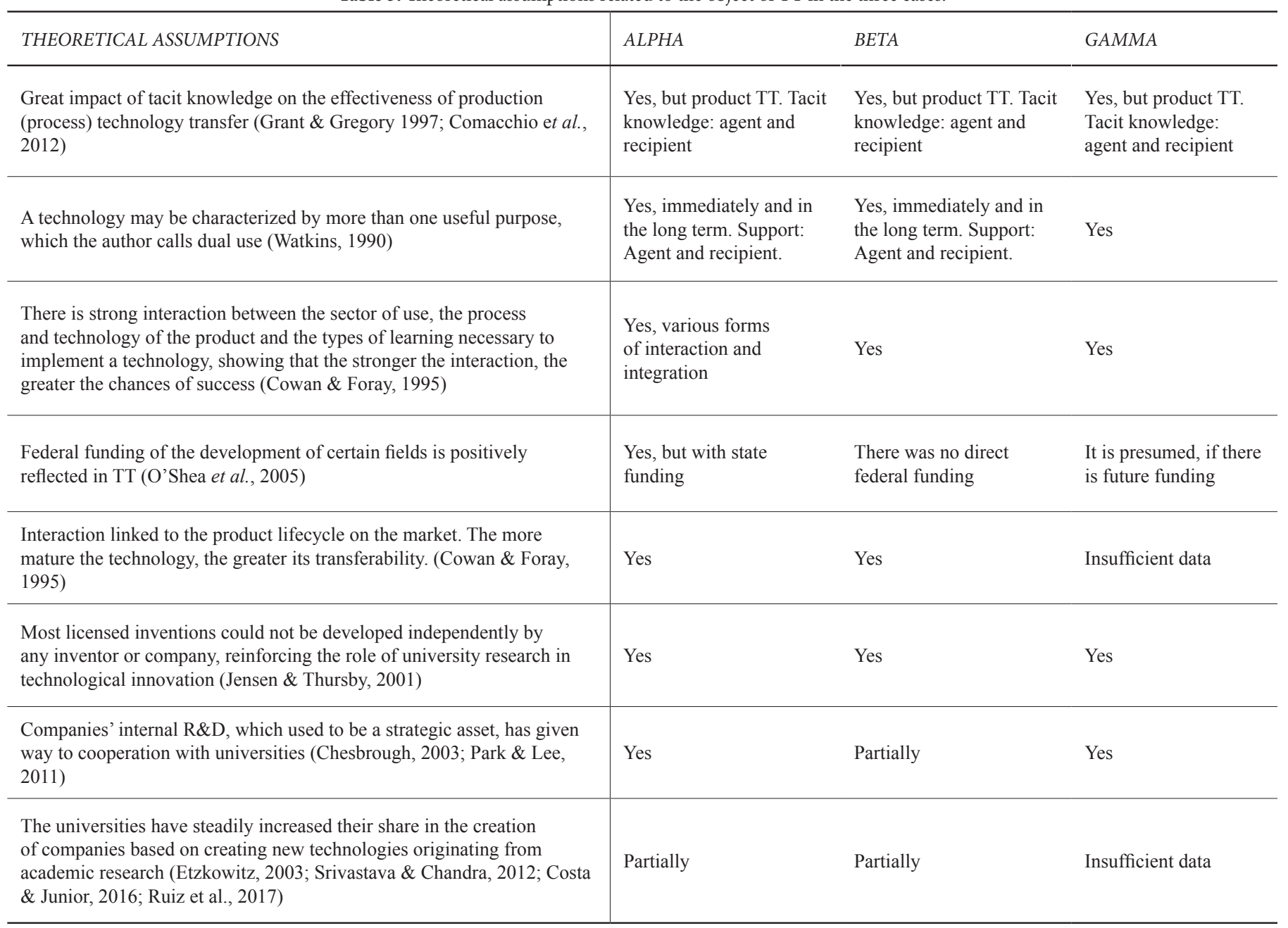

Regarding the strong impact of tacit knowledge on the effectiveness of production (process) TT, in accordance with Grant and Gregory (1997), in all the cases, the answer was yes. However, it was also attributed to production TT by the agent and recipient (Table 5).

Of the three cases, Alpha has the greatest contribution in terms of tacit knowledge of the agent and recipient. The university (agent) contributes the improvement technique and the development of varieties and the experience it has accumulated in several projects It also contributes with the researchers' expertise. The commission (recipient) has knowledge of the crop and the need to solve problems regarding agriculture, the crop and the consumer, as well as the requirements of the market. The ability of both sides to interact is also part of the tacit knowledge, resulting from previous interactions between them and with other organizations, aided by the participative improvement technique. The tacit knowledge of other actors is also included, albeit with more limited participation (Table 5).
In the case of Beta, the initial support of the researchers who discovered the AgroBeta component in the early stages of 'absorbing' the technology was especially important, as was the tacit knowledge of those at the company to adapt and improve the technology for the market. The process went through the following stages: (1) stabilizing the chemical compound, (2) having the product approved by the EPA and (3) improving the invention for work in real life conditions (Table 5).

In the case of Gamma, the university (agent) provided continuous learning for the main researcher (GP3) through the tacit knowledge of GP1 and GP2 (with more experience) and the recipient (company and farmers) and another element, the partner (research institute). GP3 highlights greater knowledge of the market and the development of interaction capabilities with the company, with farmers and the research institute, as well as learning the use of different laboratory techniques at the vegetation house and achieving classical and parti- 
cipative improvements. GRT highlights the scientific knowledge provided by the researchers with new techniques, and because participative improvement involves information exchanges (Table 5).

Tacit knowledge is important for the effectiveness of TT, both on the part of the agent (university) and the recipient, as well as the partners involved, emphasizing in addition to knowledge exchanges, the interaction capability of all parties involved (Table 5).

Regarding the technology characterized as dual use (Watkins, 1990), in all the cases, there is evidence of this. In the case of Alpha, the Commission and the University are looking at the different uses for sweet potatoes. The recipient does this directly, publishing recipes for new dishes with sweet potatoes and creating new products such as Alpha Gourmet Vodka. The agent does it indirectly and in the long term, including researchers from another department of AU to develop new forms of processing sweet potatoes, creating a new product such as 'purified sweet potato mash'. In the case of Beta, it occurs directly, with the recipient striving to use the technology in different fruits in different regions. The AU agent does so with recent research involving the possible use of the technology on a smaller scale for small farmers. In the case of Gamma, advances were forecast for the new variety, with great chances of increased ginger production, new commercial partnerships and partnerships with the university, as well as the return of former farmers and the involvement of new ones in expanding the trade of natural and processed ginger by Gamma (Table 5).

The premise of Cowan and Foray (1995) is confirmed, claiming that there is strong interaction between the sector of use, the process and the technology of the product and the types of learning necessary to implement a technology. They highlight that the stronger the interaction, the greater the chances of success. In the case of Alpha, strong integration, growth and consolidation of sweet potato production was confirmed. Institutions (government, university and recipients) worked in partnership, integrating the links of the production chain, expanding quantitatively and qualitatively. In the case of Beta, the AgroBeta business was consolidated based on transferred technology, benefitting the entire production chain. Beta is also investing in and marketing equipment for the application of Beta (BP) and other postharvest and pre-harvest products with similar purposes to those of Beta. In the case of Gamma, it is assumed that the domination of GRT in the production chain will mean greater success in gingerrelated activities, expanding the business in terms of both quality and quantity, despite GRT already leading the TT process (Table 5).

The arguments of O'Shea et al. (2005), that federal funding for the development of certain fields is positively reflected in TT, is confirmed only for Alpha, but only in the case of state investments. Investment in research and the extension of sweet potatoes, especially by the state government, is of national prominence, greater than in other states that produce this crop. One aspect of state investment is the AU itself, which is a state university. This investment strengthens research and sweet potato production in the state. In the long term, it involves academia and farmers, providing benefits that extend to the production chain. In the case of Beta, this premise cannot be identified because the research that led to the component had another purpose. In the case of Gamma, it is assumed that federal or state incentives for small ginger farmers mean further advantages for business after the production of the new variety (Table 5).

When linking interaction to product lifecycles on the market, the claims of Cowan and Foray (1995), that the more mature a technology is, the greater its transferability, is confirmed for Alpha and Beta, that the more advanced the stage of the lifecycle, the greater its expansion. It is important to highlight the report of ETT1 at AU regarding the need to work on discoveries and inventions for the market, which is one of the main challenges at AU. In the case of Alpha, with applied research and participative improvement, this maturity is easier to achieve. In the case of Beta, efforts were made to market the AgroBeta technology, seeking the involvement of researchers from AU. In the case of Gamma, it is not yet possible to evaluate the behavior of the technology with regard to the assumptions of Cowan and Foray (1995) (Table 5).

The claim by Jensen and Thursby (2001) that most licensed inventions could not be developed by any inventor or company independently, reinforcing the role of university research in technological innovation, is evident in these cases (Table 5).

Chesbrough's (2003) claim that a company's internal R\&D used to be a strategic asset that has now given way to cooperation with universities can be confirmed in the case of Alpha and Gamma. With regard to Alpha, the recipient, the Commission, a non-profit organization, presents a cooperation strategy with $\mathrm{AU}$ for innovation, with no internal R\&D structure. For Gamma, it was seen that the micro enterprise that acts as the technology recipient is open to partnerships with other organizations as a source of R\&D and, consequently, innovation, as it is an 'open organization' (Table 8). In the case of Beta, this is partially confirmed, as the knowledge applied by the company with a team of researchers was fundamental in making the technology feasible and diffusing it later (Table 5).

Regarding the claims of Etzkowitz (2003), that universities have constantly increased their level of participation in the creation of companies to create new technologies through academic research, this is partly the case for Alpha and Beta. It is partly the case for Alpha because, in the long term, new businesses have been developed in the production chain, including some with the support of $\mathrm{AU}$, although it originated at other departments. It is partly true for Beta because it did not occur directly. The company was created to market the technology that was expanded, leading to the product being applied to other fruit and the international market. Furthermore, as there were benefits to elements of the production chain, it is possible that new businesses were created. A new job was also created, the 'Beta applicator', along with equipment for this activity. There are insufficient data on Gamma to confirm the authors' arguments (Table 5).

In none of the cases was there participation or influence from a science park (Bozeman, 2000), research consortium (Aldrich et al., 1998) 
or cooperative research center (studied by Gray, 2008 and Boardman \& Gray, 2010). In the cases of Alpha and Gamma, pre-existing relationships influenced the effectiveness of the TT, while in the case of Beta, it was only through the first company, which acquired the technology and as an entrepreneur glimpsed an opportunity in the apple market, and sought to market it, which resulted in the license to DD Chemicals (Table 6).
Informal means (Grimpe \& Fier; 2010 and Bradley, Hayter \& Link, 2013) were identified in the case of Alpha prior to the TT and in Beta after the TT, in the case of Beta when there was cooperation between researchers and DD Chemicals to adapt the technology to the 'point of marketing. In the case of Gamma, the TT was informal, considering that there is no licensing (Table 6). The relationship between the theoretical assumptions of TT means and the empirical cases is summarized in the following table:

Table 6. Theoretical assumptions related to TT in the three cases.

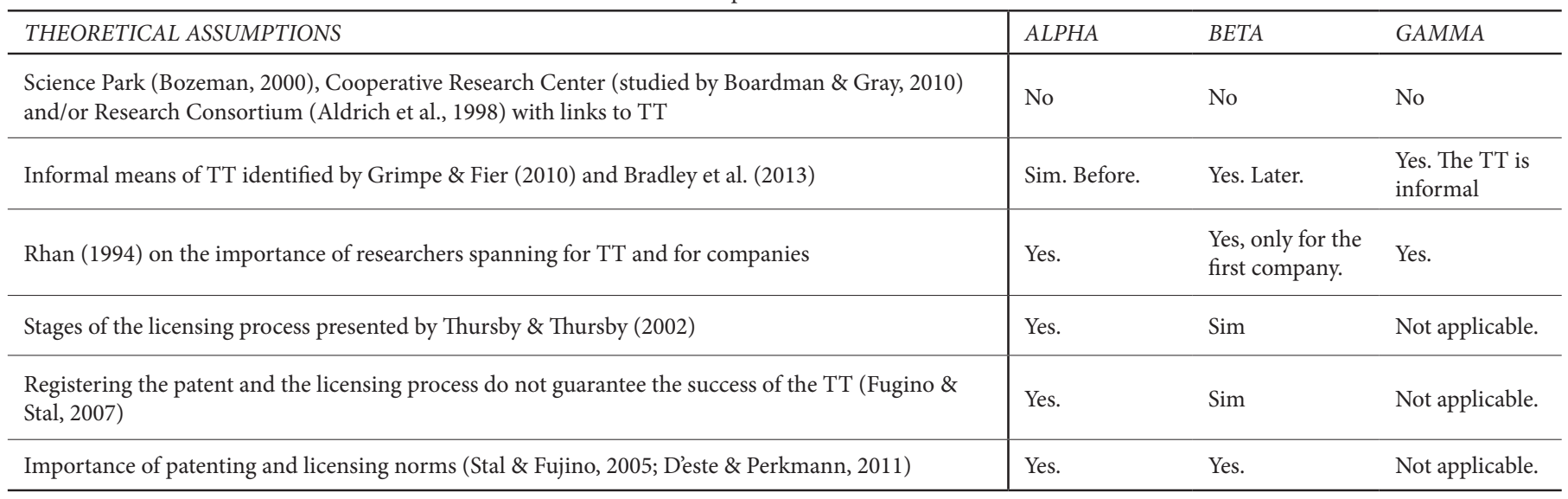

In all the cases, the researchers were characterized as spanning (Rhan, 2000), but in the case of Beta, only in the case of the first company that led to TT later to DD Chemicals (Table 6).

As for compliance with the stages of licensing identified by Thursby and Thursby (2002), in the case of Alpha and Beta, these stages are identified, but in greater detail. This does not apply to Gamma, as the TT is informal (Table 6).

The claim that patenting and licensing are not synonyms of successful TT (Fugino \& Stal, 2007) is valid for Alpha and Beta. It is not applicable in the case of Gamma, as its TT is informal, only requiring registration with the Ministry of Agriculture. The importance of patenting and licensing norms (Stal \& Fujino, 2005) is evident in the cases of Alpha (patent itself) and Beta (specific patent of a variety of vegetable, known as a cultivar), but does not apply to the case of Gamma, as its $\mathrm{TT}$ is informal (Table 6).

\section{Conclusion}

Considering the peculiar aspects of National Innovation Systems in each country, in Brazil and the USA an attempt was made to analyze the agriculture schools of Brazilian and American universities. The study of these cases enabled a detailed description of the alignment between the object and means of U-FTT and a discussion of theoretical assumptions (Tables 5 and 6). Thus, it was possible to conclude that the U-FTT model is contingent, i.e., the object and means of UFTT are in continuous alignment and construction. Therefore, they are open to new contributions and theoretical assumptions, as summarized in the following table.

Table 7. Theoretical assumptions related to the object and means of TT in the three cases.

\begin{tabular}{l|l}
\hline VARIABLES & ASSUMPTIONS \\
\hline \multirow{5}{*}{ TT object } & $\begin{array}{l}\text { (1) Federal funding for the development of certain areas reflects positively on TT (O’Shea et al., 2005); (2) Most licensed inventions could } \\
\text { not be developed independently by any inventor or company, strengthening the role of university research in technological innovation } \\
\text { (Jensen \& Thursby, 2001). (3); Companies' internal R\&D used to be a strategic asset, but has now given way to cooperation with universities } \\
\text { (Chesbrough, 2003; Park \& Lee, 2011); (4) Universities have constantly increased their participation in the creation of companies based on } \\
\text { the creation of new technologies that originated in academic research (Etzkowitz, 2003; Srivastava \& Chandra, 2012). }\end{array}$ \\
\hline TT means & $\begin{array}{l}\text { (5) The participation of the university in Cooperative Research Centers serves as a mechanism for national and state governments and pri- } \\
\text { vate companies to achieve social and economic results with science and technology, as well as scientific results (Boardman \& Gray, 2010); } \\
\text { (6) Informal TT means identified by Grimpe \& Fier (2010) and Bradley et al. (2013); (7) Stages in the licensing process presented by Thursby } \\
\text { \& Thursby (2002); (8) The registration of patents and the licensing process do not guarantee the success of TT (Fugino \& Stal, 2007); (9) The } \\
\text { importance of licensing and patenting norms (Stal \& Fujino, 2005). }\end{array}$ \\
\hline
\end{tabular}


Based on the existing studies on U-FTT (Bozeman, 2000; Hendriks, 2012; Susanty et al., 2011; Roper, Gormley \& Hewitt-Dundas, 2013), the present study differs and makes significant contributions through the following factors: (1) it concentrates on TT from the perspective of agriculture schools of public universities for food products; (2) its analysis is aligned with the object and means of U-FTT, considering the perspectives of the agents and recipients of the technology and theoretical assumptions; (3) it investigates the phenomenon of $\mathrm{U}$ FTT in terms of formal and informal means; and (4) it is an interinstitutional and international study, considering aspects of the macro context, especially characteristics of national innovation systems in each country.

A suggestion for future studies would be to look at the effects of TT considering the assumptions raised and validated in this study. Other studies could focus on the expansion of the original TT to other regions by the recipient, or to other countries, adapting it to other cases of food.

\section{References}

Aldrich, H.; Bolton, M.; Baker, T.\& Sasaki, T. (1998). Information exchange and governance structures in US and Japanese R\&D consortia: institutional and organizational influences. IEEE. Transactions on Engineering Management, 45(3), 263-275.

Ankrah, S., \& Omar, A. T. (2015). Universities-industry collaboration: A systematic review. Scandinavian Journal of Management, 31(3), 387-408

Babbie, E. (1998). The practice of social research. Belmont: Wadsworth Publishing Company.

Baglieri, D., Baldi, F., \& Tucci, C. L. (2018). University technology transfer office business models: One size does not fit all. Technovation. Bidault, F.\& Fischer, W.A. (1994). Technology transactions: networks over markets. R\&D Management. 24, 373-386.

Bigliardi, B., Galati, F., Marolla, G., \& Verbano, C. (2015). Factors affecting technology transfer offices' performance in the Italian food context. Technology Analysis \& Strategic Management, 27(4), 361-384.

Boardman, C.\& Gray, D. O. (2010). The new science and engineering management: cooperative research centers as government policies, industry strategies, and organizations. Journal of Technology Transfer, $35,445-459$.

Bozeman, B. (2000). Technology transfer and public policy: a review of research and theory. Research Policy. 29. 627-655.

Bozeman, B., Papadakis, M. \& Coker, K. (1995). Industry perspectives on commercial interactions with federal laboratories: does the cooperative technology paradigm really work?, Report to the National Science Foundation. Research on Science and Technology Program, January.
Bozeman, B., Rogers, J., 1998. Knowledge value collectives: the proof of science is in the putting. Paper presented at the Conference on Laboratory Evaluation, Ecole des Mine, Paris, France, June 12-14, 1998.

Bradley, S. R., Hayter, C. S., \& Link, A. N. (2013). Models and methods of university technology transfer. Foundations and Trends in Entrepreneurship, 9(6), 571-650.

Cervo, A. L. \& Bervian, P. A. (1983). Metodologia científica: para uso de estudantes universitários. 3. ed. São Paulo: McGraw-Hill.

Chesborugh, H. W. (2003). Open innovation: the new imperative for creating and profiting from technology. Boston, Massachusetts. Harvard Business School Press.

Closs, L. Q., Ferreira, G. C. (2012). A transferência de tecnologia universidade-empresa no contexto brasileiro: uma revisão de estudos científicos publicados entre os anos 2005 e 2009. Gestão e Produção. São Carlos, 19(2), 419-432.

Comacchio, A., Bonesso, S., \& Pizzi, C. (2012). Boundary spanning between industry and university: the role of Technology Transfer Centres. The Journal of Technology Transfer, 37(6), 943-966.

Costa, P. R., \& Junior, S. S. B. (2016). Atuação Dos Núcleos De Inovação Tecnológica Na Gestão Da Cooperação Universidade-Empresa. Revista de Administração FACES Journal, 15(4).

Cowan, R., Foray, D. (1995). Quandaries in the economics of dual technological and spillovers from military to civilian research and development. Research Policy. 24(6), 851-869.

Creswell, J. W. (2014). Investigação qualitativa \& projeto de pesquisa: escolhendo entre cinco abordagens. Porto Alegre: Penso.

Crow, M., Bozeman, B. (1998). Limited by Design: R\&D Laboratories in the US National Innovation System. Columbia Univ. Press, New York.

D'este, P., \& Perkmann, M. (2011). Why do academics engage with industry? The entrepreneurial university and individual motivations. The Journal of Technology Transfer, 36(3), 316-339.

De Fuentes, C., \& Dutrénit, G. (2016). Geographic proximity and university-industry interaction: The case of Mexico. The Journal of Technology Transfer, 41(2), 329-348.

Di Gregorio D. \& Shane, S. (2003). Why Do Some Universities Generate More Start-Ups than Others? Research Policy. 32(2), 209-227. Eisenhardt, K. M. (1989). Building Theories from Case Study Research. Academy of Management Review, 14(4), 532-550

Etzkowitz, H. (2003). Research Groups As 'Quasi-Firms': The Invention of the Entrepreneurial University. Research Policy, 32(1): 109121. 
Etzkowitz, H., \& Leydesdorff, L. (2000). The dynamics of innovation: from National Systems and "Mode2" to a Triple Helix of universityindustry-government relations. Research Policy. 29 (2), 109-123.

Garnica, L. A. \& Torkomian, A.L. V. (2009). Gestão de tecnologia em universidades: uma análise do patenteamento e dos fatores de dificuldade e de apoio à transferência de tecnologia no Estado de São Paulo. Gestão e Produção, 16(4), 624-638.

Grant, E.B. \& Gregory, M.J. (1997). Tacit knowledge, the life cycle and international manufacturing transfer. Technology Analysis and Strategic Management. 9 (2) 149-161.

Grimpe, C. \& Fier, H. (2010). Informal university technology transfer: a comparison between the United States and Germany. The Journal of Technology Transfer. 35(6), 637-650.

Harmon, B., Ardishvili, A., Cardozo, R., Elder, T., Leuthold, J., Parshall, J., Raghian, M., \& Smith, D. (1997). Mapping the university technology transfer process. Journal of Business Venturing, 12(6), 423-434.

Henderson, R., Jaffe, A. \& Trajtenberg, M. (1998). Universities as a source of commercial technology: a detailed analysis of university patenting, 1965-1988. The Review of Economic and Statistics, 80(1), 119-127.

Hendriks. J. (2012). Technology transfer in human vaccinology: a retrospective review on public sector contributions in a privatizing science field. Vaccine, 30 (44). 6230- 6240.

Jensen, R. \& Thursby, M. (2001). Proofs and prototypes for sale: the licensing of university inventions. American Economic Review, 91(1), 240-259.

Lai, W. H. (2011). Willingness-to-engage in technology transfer in industry-university collaborations. Journal of Business Research, 64(11), 1218-1223.

Lee, Y.S. (1996). 'Technology transfer' and the research university: a search for the boundaries of university-industry collaboration. Research Policy 25 (6), 843-863.

Link, A. N.; Siegel, D. S. Bozeman, B. (2007). An empirical analysis of the propensity of academics to engage in informal university technology transfer. Oxford Journals, 16(4), 641-655.

Lynn, L.H., Reddy, N.M.\& Aram, J.D., 1996. Linking technology and institutions - the innovation community framework. Research Policy, (25)1, 91-106.

Malecki, E. \& Tootle, D. (1996). The role of networks in small firm competitiveness. International Journal of Technology Management. 11 (1-2), 43-57.

Malecki, E. (1981). Government funded R\&D: some regional economic implications. The Professional Geographer. 33(1), 72-82.
Melo, P. A. de. (2002). A cooperação universidade/empresa nas universidades públicas brasileiras. Tese de Doutorado. Programa de Pós-Graduação em Engenharia de Produção, Universidade Federal de Santa Catarina, Florianópolis, Brasil.

Miller, K., McAdam, R., \& McAdam, M. (2018). A systematic literature review of university technology transfer from a quadruple helix perspective: toward a research agenda. R\&D Management, 48 (1), $7-24$.

Minayo, M. C. de S. et al. (1994). Pesquisa social: teoria, método e criatividade. Petrópolis -RJ: Vozes.

Mowery D. \& Sampat, B. (2005). Universities in national innovation systems. In: Fargerberg, J.; Mowery, D.; Nelson, R. (Orgs.). The Oxford Handbook of Innovation. New York: Oxford University Press.

Mowery D. C., Nelson, R. R., Sampat, B, N.\& Ziedonis, A. A. (2001). The growth of patenting and licensing by U.S. universities: an assessment of the effects of the Bayh-Dole act of 1980. Research Policy. 30(1), 99-119.

O'shea, R. P., Allen, T. J., Chevalier, A., \& Roche, F. (2005). Entrepreneurial orientation, technology transfer and spinoff performance of US universities. Research policy, 34(7), 994-1009.

Park, S. H., \& Lee, Y. G. (2011). Perspectives on Technology Transfer Strategies of Korean Companies in Point of Resource and Capability Based View. Journal of technology management \& innovation, 6(1), 161-184.

Piper, W.S., Naghshpour, S. (1996). Government technology transfer: the effective use of both push and pull marketing strategies. International Journal of Technology Management. 12(1), 85-94.

Roper, S., Gormley, B., \& Hewitt-Dundas, N. (2013). Knowledge and Technology Transfer Links: The Differential Connectivity of Publicly Funded University and Company-Based Research Centres.

Rosenberg, N. \& Nelson, R.R., 1994. American universities and technical advance in industry. Research Policy. 23, 323-348.

Ruiz, M. S., Da Costa, P. R., Kniess, C. T., \& Ribeiro, A. P. (2017). Proposal of a theoretical model for the implementation and scalability of science parks: a case study. RAI - Revista de Administração e Inovação, 14(1), 2-15.

Siegel, D. S., Waldman, D., Link. A. (2003). Assessing the impact of organizational practices on the relative productivity of university technology transfer offices: an exploratory study. Research Policy. 32 (1), 27-48.

Srivastava, P., \& Chandra, S. (2012). Technology Commercialization: Indian University Perspective. Journal of technology management \& innovation, 7(4), 121-131. 
Stal, E. \& Fujino, A. (2005). As relações universidade-empresa no Brasil sob a ótica da Lei de Inovação. Revista de Administração e Inovação, 2(1), 5-19.

Susanty, A., Puspitasari, D., Puspitasari, N. B., \& Sinthani Ninditarini, M. R. (2011. Preliminary Study of Key Success Factors for Effective Knowledge Transfer in SMEs Batik (Case Study SMEs Batik in Solo). In Proceedings of the 2011 International Conference on industrial Engineering and Operations Management Kuala Lumpur, Malaysia.

Thursby, J. G., \& Thursby, M. C. (2002). Who is selling the ivory tower? Sources of growth in university licensing. Management Science, 48(1), p. 90-104.
Watkins, T. (1990). Beyond guns and butter: managing dual-use technologies. Technovation 10(6) 389-406.

WEF. (2015). World Economic Forum. The Global Competitiveness Report 2014 - 2015. Recuperado em 03 julho, 2015, de http://www. weforum.org/reports/global-competitiveness-report-2014-2015

Yin, R. K. (2001). Estudo de caso. Planejamento e métodos. Porto Alegre: Bookman,

Zucker, L. G.\& Darby, M. R. (2001). Capturing technological opportunity via Japan's star scientists: evidence from Japanese firms' biotech patents and products. The Journal of Technology Transfer, 26(1-2), pages 37-58. 